\title{
ULUSAL NITELI ve LAIK TOPLUMLU DEMOKRASININ KURULUŞU
}

\section{Prof. BAHRI SAVCI}

Anadolu thtilaline kadar olan evrede, türkler, bir parlamenter demokrasının dış ögelerine dayalı bir uygulamayı tanımış oldular: Egemenliği halk ortaklığına kadar getirmişlerdi. Böylece iktidar beșerileştirilmiş, ama meşruti manarş1 içinde, gene de tam demokrasileşmemişti. Oysa ki, tam demokrasiye ulaşmak için, yeni bir dönemę̧ noktasını aşmak gerekiyordu. Bu dönemeçten sonra, ulusal nitelikte, artık tüm halka dayalı, demokrasi rejiminin ilkeleri bulunmuş ve onlara göre gerekli temelleri atılmıştır. Kurumlari korunmuştur. Ve demokrasi lâisize edilmiştir. Bu, iktidarın, tamamiyle. beşerîleştirilmesi olayını oluşturmuş. Sonra da, bu demokrasinin toplumsal temeli yaratılmak istenmiştir:

I. IKTIDARI BEŞERILESSTIREREK, TÜM HALKA DAYALI BIR DEMOKRASILEŞMENIN ILKELERI :

Mondros silâh bırakışması (30.X.1918), Osmanlı Devletinin pek ufaltılarak, kendine özgü bir sömürge hükûmeti haline getirilmesinin başlangıcı idi, Bu küçük Osmanlı Hükûmetinin, iktisat kaynağı bulunmıyacak, bağımsız bir ulusal politikası ve onun dayanağı ordusu olmayacaktı. Onun için Musul.dan başlayıp, İzmir'den geçen, Samsun ve Merzifon'a kadar uzanarak bir işgaller halkası ile Başkent bile çevrilmişti.

Bu ufalanmayı sağlamak için, türlü azınlıkların kendi ulusalcı duygularını kıştırtan dernekler kurulmuştu: Mavri Mira Derneği, Bizans İmparatorluğunu canlandıracaktı. Puntos Derneği, Karadeniz kıyılarında, İsa.dan III Yüzyıl sonraki Puntos Krallığı'nı canlandıracaktı. Ermenilerin kurduğu bir dernek de, Erivan'da kurulmuş olan Ermenistan Cumhuriyeti'nin, Anadolu'nun Doğu ve Güney-Doğu'sunda Ermenileri de kapsamasını istiyordu. Kürdistan Teali Derneği de, hir ayrı Devlet kurmak diliyordu. 
Bunkardan başka, Saltanat ve Halifelik çekirdeği üzerinde kurulacak ve yabancıların koruması altına sokulacak bu küçük sömürü devletine razı Müslüman - Türk dernekleri de vardı ki, bunların tümü, Anadolu'da yeni bir direnme gösterilmesine karşı idiler : Teali-islâm Cemiyeti, Ingiliz Muhipler Cemiyeti, Amerikan Mandacıları gibı.. Yâni 1918'in sonlarında durum şöyledir: İkiyüz yıla yakın bir süre içinde sürdürülen yenileşme, demokrasileşme olayı, sona ermiş gözükür. Hattâ Devlet yaşamının sona erdiğine inananelar vardır.. Olabilecek olan şunlardan ibaret gözükür : Batı'nin karşısında, yenileşme olanaksızdır. ve, demokrasileşen bir siyasal iktidar olayı kurulması boşunadır; olacak iş değildir. Batı'nın acımasına, korumasına ve barışcıların, ümanistlerin ileri sürdüğü kimi prensiplere sığınarak Batı'nın uydusu olunmasına kendini bırakmak, en geçerli yoldur. Gene de İstanbul'da yaşamını, varlığını sürdürecek bir Halifelik - Padişahlık çekirdeği, Batının acımasını korumasını elde etmeye yarayacak bir sömürge hükûmeti görevi görür, o kadar... Yaşama dayanağı; tüm büyük ülkülerden uzakta, Ilâmcı otokrasi ilkelerine dayalı bir Padişahlık ile, onun sağlayacağı yabancı korumasidir.

$\mathrm{Bu}$ yılgınlara karşı, onların Hilâfet - Saltanat otokrasiciliğine karşı, onların hoşgördükleri, hatâ yararlı gördükleri işgallere karşı, bu işgallerden kendi irk temellerine dayalı devletlerini kurmak için yararlanan türlü dış ögelerine örgütlerine karşı, Imparatorluğun Türk ögeleri de, türlü bölgelerde, ulusal nitelikte dernekler, örgütler kurmuşlardır. Bunların, beşerîleşerek demokrasileşme bilincinin - hattâ bilinç üstü olmasa bile bilinç altı gelişen bir demokrasileşme sürecinin - araçları olduğu, ilk anda, ileri sürülemez. Ama, bunların, yabancı işgallere silâhla karşı koyma örgütlenmesi devinimi (hareketi) oldukları bir gerçektir. Bu nedenle, ve Türk Ulusu çekirdeği üzerinde olmaları ile, "ulusal» bir nitelikleri oldukları da, aynı ölçüde kesin bir gerçektir. Giriştikleri silâhlı direnişi, Osmanli parçalansa bile, bölgelerinde bir Cumhuriyet olarak ulusal varlığı sürdürmeye kadar götürmeyi düşündükleri bile olmuştur. (Trakya-Paşa Ili Müdafaai Hukuk-u Osmanî Cemiyeti gibi) aymca evrenin diyalektiğinde, bunların genel inanış «paşif görüş politikası» nın bir çelişkisi oldukları da kuşkusuzdur.

Evet, evrenin genel inanışı ; "Hilâfet ve Saltanat makamının» kurtuluşunu herşeyin önüne almıştı. Onun için savaşı kazananların göcendirilmemesi pasifliğini güdüyordu.

$\mathrm{Bu}$ ulusal örgütler ise, birbirleriyle bağlantılı olmadıkları halde, hiç olmazsa bölgesel bir direnci deyimliyorlardı. Onlar da, as- 
lında Halifelik - Padişahlık makamına karşı bir dinamızm içinde değillerdi. Bölgelerinde ulusal değerlere dayalı bir yaşamı ve olanağı varsa, Osmanlı Devletini, şimdi Türk çekirdeği üzerinde bağımsız olarak sürdürmeyi öngörürler. İşte, Doğu Illlerindeki dernek, Ermenilere karşı Doğu İllerini korumak içindir. Karadeniz kıyılarindaki, buraların yabancılara verilmesini ve buralarda bir örnek Devlet kurulmamasını sağlamak içindir. Ege Bölgesindeki iki dernek de, İzmir ve çevresinin Türk olduğunu savunarak buraların Yunanlılara eklenemiyeceğini, dünyaya bilim yoluyle, işgalci Yunanlılar ile onları destekleyenlere de eylem yoluyla anlatmak içindir.

Görülüyor ki, Hilâfet ve Saltanat makamını, doğrudan doğruya «karşıya» atmamıştır. Doğrudan doğruya, Devletin demokrasileştirilmesi amacı da yoktur ortada.. Bu da doğaldır. Çünkü 1918'in içinde olan olay; Osmanlı'nın islâmlık ile birlikte parçalanmasıdır. Türk bölgelerin ondan koparılarak yabancılaştırılmasıdır. O halde 1918 sonlarındaki sorun da, bu olaydan çıkmak üzere, bölgenin Türklük ve İslâmlık karakterine sığmayan bu işgale, bu ilhaka karşı korunması; bunun da, bir «Devlet kavramı» "Devlet birliği» içinde olması zorunluğu dolayısiyle de, Halifelik - Padişahlık makamının da, bu birìğin simgesi olarak kurtarılması sorunudur. Belki yalnız, Trâkya - Paşaeli Müdafaai-Hkuk-u Osmanî Cemiyetidir ki, Osmanlı parçalansa bile, bölgede bir Cumhuriyet olarak Türklerin varlıklarını gene de sürdürmesini, açıkça öngörmüştür.

Fakat tam bu arada, bir Mustafa Kemə. inanışı, devreye girmiştir. Buna göre, Osmanlılık, artık kesin olarak parçalanmıştır. Geleneksel yapısını yenileştirmeye XVIII'inci Yüzyıl başındanberi uğraştığımız Osmanlı Devleti bu modernleşmesini tüm algılayamadan kesin olarak, sona ermiştir. Bunu da, Osmanlılığnn içindeki türlü ırklar-diller-ulusçuluklar, Batı kapitalizminin Doğu'ya yüklediği ekonomik sömürülme rolünün, Birinci Dünya Savaşı sonu versiyonu doğurmuştur. Ama, ortada bir avuç da kalmış olsa, bir Türk çekirdeği vardır. Osmanlılıktan kalıt olarak da, Anadolı ile Trâkya'nın bir bölümüne, Türk Ulusçuluğuna ve yenileşmesine elverişli olarak, el altındadır. Bu Türk Ulusçuluğu ile, yenileşmesinde, Padişah ile Halifecilik, kullanılacak olumlu öge olmaktan çıkmıştır. Çünkü bu iki makamın, kavramın sahibi olan zat, Tanrı.nın gölgesi olmaktan gelen «Hukuk-u Hükümranî» sini sömürgeci Devletler ile, Osmanllığın parçalanmasını isteyen ırklar ulusçuluğuile anlaşarak, ülkenin paylaşılmasına razı olma yolunda kullanmaktadır. Öyle ise, Padişah Hükûmetinin İtilâf Devletleri'nden - yâni düşmanlardan- yar. 
dım umma politikası bâtıldır. Osmanlı Saltanat ve Halifeliğini yasatmağa çalışmak da, Ulusa karşı en büyük kötülüğü işlemektir. Bağımsız, yeni bir Devlet kurmak gereklidir.

Bu yeni Devlet, Halife - Sultanlık dışında olacağından, tüm beşeri temeller üzerinde olacaktır. Padişah gibi, onun kulluğundaki Âyan gibi geleneksel değerlere ve kurumlara dayanmayacağı için, yalnızca Türk Ulusuna, Türk ulusçuluğuna dayanacağı için, halka dayalı bir demokrasileşme olacaktır.

$\mathrm{Bu}$, beşerí temeller üzerindeki halka dayalı demokrasinin ilkeleri de; Amasya Genelgesinde (22/23.6.1919), Erzurum Kongresi kararlarında (23 Temmuz - 6 Ağustos 1919), Sivas Kongresi kararlarında (11-12 Eylül 1919), Türkiye Büyük Millet Meclisinin kabul ettiği kararlarda belirmiş ve gelişmiştir.

Bunları, şöylece işaret etmek olanağımız vardır :

\section{A - Siyasal İlkeler :}

a) Ulusal Birleşik Direnme Prensibi: Mustafa Kemal'in Anadolu'ya çıkışı, bir direnmenin başlatılmasıdır. Ulusal Kurtuluş Savaşı, geleneksel ve eskil siyasal değerler ve payını arıtlanması ile yenilerinin konması devrimleri, bu direnmenin ürünüdür. Türkiye'nin modern demokrasisi, bir geleneksel ve eskil Devlet yap1sına ve kurumlarına direnmeden çıkar. Ama, sözkonusu olan direnme, asıl, sonradan demokrasileşmenin kurumlarını getirecek olan bağımsızlığı elde etme direnmesidir.

Mustafa Kemal'in Samsun'a çıkışından sonra ve hemen giriştiği bir iş de, Samsun'daki Ingiliz temsilcilerine, Ingiliz subaylarına ve İstanbul Hükûmetine bu direnç duygusunu bildirmektir: «Türkler, kısa bir süre de olsa, başka Devletlerin yönetimini kabul etmez. İzmir'in Yunanlılar tarafından alınmasına, bu Ulus birleşerek karşı koyacaktır demiştir. Bölgedeki Kolordu Komutanlarına; kurtulmak için hep birlikte davranışa geçmenin ve ulusal bütünlüğü kurup korumanın gerektiğini bildirmiştir. Samsun'a çıkışının daha on günü dolmadan, tüm Kolordu Komutanlarına, Valilere, Mutasarrıflara, halk gösterileri düzenliyerek, düşman saldırılarını protesto etmelerini buyurmuştur. Erzurum Kongresi, her türlü yabancı saldırısına ve içişlerimize karışmasına, ulusu, birleştirerek direnecektir. Sivas Kongresi'nde, her karış toprak için savunmaya ve Itilâf Devletlerine karşı gelmeye karar verilmiştir. Mandacılı̆̆ın ve her türlü dıştan gelecek koruyuculuğun karşısına çıkılmıştır. Öyle ki, ya ölümün kucağına düşülecektir, ya bağımsızlık elde edil- 
miş olacaktır. Öyle ki, Türkler coğrafya olarak, yabancı devlet tutsaklığında bırakılmıyacaktır. Bütün Türkleri kapsayan bir ulusal Devlet kurulacaktır. Ve bunun içinde, yabancı Devletlerin, içişlerimize ekonomik yaşamımıza, bağımsızlığımıza karışmalarına olanak verilmiyecektir.

Mustafa Kemâl'in direnme ilkesi; Heyeti Temsiliye Ankara'ya geladikten sonra (27 Aralık 1919), Itilaf Kuvvetlerinin, yalnızca savaş gemilerini İstanbul Limanında tutma ile yetinmeyip, 16 Mart 1920 'de, karaya asker de çıkarmaları üzerine, İstanbul Hükûmeti gibi buna boyun eğmeyip, 19 Mart 1920 'deki bildirisinde pek açık deyimlenmiştir: Ülke ve Ulus, yalvarmakla kurtulmaz. Devlet işleri, merhamet dilenerek yürütülemez. Yaşam, savaşım ve çarpısma demektir, başarı savaşım ile elde edilir, diyen sözlerinde, pek açıkça belirir.

b) Ulusal Egemenlik-Ulusal Güç Ilkesi : Ünlü Amasya genelgesi ile Erzurum Kongresi, demokrasimizin yapısal değişmesi sürecinde bir aşama olan bir ilkeyi belirtmişlerdir. Bu, göksel (semavî) iktidar kavrammdan tüm kopup, ulusal güç, ulusal egemenlik, ulusun iktidrı kavramına ve onun gerektirdiği lâik kurumları geçişin ilkesidir.

Amasya Genelgesi, en büyük gücün ulusta olduğunu belirtmiştir: Ulusun yazgısını, bağımsızlığını, gene Ulusun azim ve kararının kurtaracağını belirtmiştir. Bu ulusal karar da, bir merkezsel kuvvet tarafından, bir oligarşi tarafından belirlenip deyimlenmiyecektir. Ulusal bir kurultay tarafından belirtilecektir. Erzurum Kongresi'ne göre ise, herşeyin yapıcısı, ulusal kuvvet olacaktır (Kuvayi Milliye'nin âmil olması). Artık, bir Halife - Sultan, ya da bir parti oligarşinin merkezsel istemi (iradesi) egemen olmayacaktır. Klâsik demokrasinin baş ilkesi, temel kurumu olan ulusal istem egemen olacaktır irade-i milliye hâkim kılınacaktır). Sivas Kongresi'nde bu ulusal güç, bu ulusal egemenlik; adının gereği olarak, bütün yurdu temsil edecektir. Bir örgütü de vardır: Heyeti Temsiliye.. Fakat, buradan Anadolu'da, bir yeni Meclisin kurulmasına geçilecektir.

$\mathrm{Bu}$ Meclis, ulusal egemenlik-ulusal güç-yerel ve beşerì iktidar yolu ile demokrasileşmenin ilk temel taşları olan ilkeleri koymuştur.

Artık, bir yeni Hükûmet kurulacaktır. Bu hükûmet, İstanbul'dan ayrı bir hükûmet olacaktır. İstanbul Hükûmetinin göksel (semavî) başı olan Padişahlık ile, bu yeni hükûmetin bir ilintis olmı- 
yacaktır. Çünkü, İstanbul'daki Halife - Sultan kurumu artık, ulusal istem (irade) ve onun üstünlüğü ile bağdaşamaz. Batılı demokrasinin temel taşı, ulusal istemdir. Ve onun üstünlüğüdür. İslâmî Kamu Hukukuna göre Hükümdar, Halife-Sultan en üstün olmak gerekir. Şimdi ise, Türkiye Büyük Millet Meclisinin üstünde bir kuvvet tanınmaz. Çünkü bu Meclis, en üstün olan ulusal istemin belirdiği tek yerdir.

Görülüyor ki,Ankara Meclisi, artık, dönüşü olmıyan bir akım halinde, ulus moral kişiliği - onun istemi - bu istemin egemenliği dolayısiyle, kendisine rakip, benzer, eşit bir güç tanımayan üstünlügü ilkelerini getirmiştir ve yerleştirmiştir. $\mathrm{Bu}$ durumda kurulan yeni sistem içinde, iktidarın metafizikten koparak beşerîleşmesiyle varılan demokrasileşme olayı içinde, Padişaha ve Halifeye yer yoktur. Sistemin teorisine göre, Halife - Sultanlığa yer yoktur. Ama, bu son tümce, henüz söylenmemiştir. Siyasal ortam elverişsizliği yüzünden.. Padişah ve Halifenin, altında bulunduğu baskıdan kurtulduktan sonra, «Meclisin düzenliyeceği esaslar içinde yerini alacağı» belirtilmekle yetinilmiştir. $\mathrm{Bu}$, ulusal egemenlik ve iktidar teorisinin Türk versiyonuna göre Sultanlık ve Halifeliğin tarihe karışmasıdır. Nitekim, 24 Mayıs 1920 Yasası ile, bu Meclis, Sultanlik ve Halifeliğin İstanbul'daki Hükûmetinin hukuksal ve siyasal. bakımlardan değeri kalmadığını, onların işlemlerinin hükümsüz düştüğünü belirtmiştir. 7 Haziran 1920 'de de, gene Osmanlı $\mathrm{Pa}$ dişahının Hükûmetinin uluslararası eylemlerinin, işlemlerinin hü-
kümsüzlüğü ilân edilmiştir.

Ulusal Kurtuluş Savaşı sona erip, Doğu Trâkya, Ankara'nın temsilcilerine ve jandarmasina teslim edildikten sonra (31 Ekim 1922), ertesi gün, T.B.M.M.'inde, «Hukuk-u Hakimiyet ve Hükümranînin» gerçek mümessilinin bu Meclis olduğu bir kez daha ilân edilerek, ona rakip, ortak olabilecek olan Saltanat, Hilâfetten ayrılarak-kaldırıldı (1 Kasım 1922). Bu, Hilâfetin henüz kalmasına ve bir Devlet dininin yasal olarak var olmasına karşın, iklidarın beşerîleştirilmesi olayının ta kendisi olmuştur. Yalnız, beşerîleşen iktidar yoluyla demokrasileşmenin en yalın biçimi olan Cumhuriyet, hemen, hemen bir yll sonra -11 ay 28 gün sonra- ilân
edildi (29.X.1923).

Böylece, 1807 'den beri başlamış bulunan «kendine yeter ve sınırsız göksel bir iktidardan, yeryüzü değerlerine, kuvvetlerine, desteklerine dayalı, insan hakları ile sinırlı, halk ile çevrili ve ortaklı iktidara geçişin son aşaması olan «yeryüzünde halk denen, 
ulus denen fenomene dayalı, kaynağını ondan alan, alanı, onun egemenliği denen bir kavramlar belirleten, ve fakat gene aynı halkın, insanın hakları ile çevrili ve sınırlı bulunan bir demokrasileşme evresine geçilmiş bulunuyordu.

Yalnız, bu demokrasileşme evresinde bile, geniş ve tüm anlamı ile «iktidarın beşeríleştirilmesi» olayı, henüz gerçekleşmemiş bulınuyordu. Ortada, T.B.M.M. ile çevrili bile olsa, bir Hilâfet kurumu vardı, Hükûmet içinde, siyasal tercih ve karara ulaşma sürecini dinsel açıdan etkileyen bir Bakanlık vardı. Yaşamı, göksel (semavî) ilkelere göre açıklayan ve düzenleyen bir eğitim sistemi de, medreselerde halâ sürüyordu. Yâni iktidarın beşerîleştirilmesi, ve böylece demokrasiye, saf ilkelerinde kavuşulması halkası tamamlanmış değildi.

Onun için, 3.3.1924'de Hilâfet kaldırıldı. Aynı gün Şer'iye ve Evkaf Vekâleti de kaldırıldı. Bununla birlikte doğal olarak, bu $\mathrm{Ba}$ kanlığın yürüttüğü medreseler de kaldırıldı. Dinsel-laik eğitim ikiliğinden ögretim birliğine varıldı. Bir ay sonra da (8.4.1924) dinsel mahkemeler kaldırılarak, yargı birliğine de varıldı. Böylece, bir açıdan, iktidar ile ilgili kurum ve örgütler, göksellikten (semavîlikten) yeryüzüne, beşerîliğe indirilmiş oluyordu. Yâni, Devlet örgütü içinde siyasal tercihi meydana getirirken, buna, dinsel kaynağa dayalı bir karışmada bulunan bir örgüt, bir makam, bir Devlet organı, bir hükûmet bölümü bırakılmamıştı. Böylelikle 1924'lerde; Ulusun yazgısını, gene Ulusun azim ve kararına bağlama - ulusal kuvveti yapıcı kılma, ulusal istemi (iradeyi) egemen kılma- egemenliği, kendisine rakip, benzer, kendisine eşit bir başka makam ile paylaşmama onu kullanmayı hiçbir bağ ve koşulla bağlamama aşamalamndan geçen, iktidamn beşerîleşmesi ve demokrasileşmesi olayı, pek gelişmiş bir evreye varmış ve çıkmış oluyordu.

Bununla birlikte, iktidarda bir göksellik gene de vardı. Çünkü, toplum, gene de göksel değerler üzerine dayanmakta sürüyordu. Çünkü toplumun, bir Devlet dini vardı. Ve bu, Devlet içindeki iktidar olayını, ister - istemez gökselliğe götürüyordu. 1924 Anayasası, (20 Nisan 1924) iktidara, göksel bir makam olan Saltanatı ve Hilâfeti ortaklıktan çıkarmışlığı, iktidarı tam olarak ulusal mal etmişliği deyimliyordu. Ama, resmen de, bir Devlet dini tanıyordu. Daha da başkası, Türkiye'de siyasal iktidar, Parlamento yoluyla, göksel nitelikı̀ olan «Ahkâmı Şeri'yenin tenfizi (uygulanması)» görevi ile de yüklenmiş bulunuyordu. 


\section{IKTİDARIN BEŞERÎLEŞEREK DEMOKRASILESMMESINAIN TOPLUMSAL TEMELLERININ DE ATILISSI :}

Devleti, resmen bir dininin bulunuşu, iktidarn beşerîleşerek demokrasileşmesi tarihsel sürecinin önünde, kurumsal engellerin sonuncusu idi. Hem bunun aşılması gerekirdi. Hem de bu sürecin toplumsal temellerinin altılması gerekirdi. Onun için, 9 Nisan 1928'de yapılan bir Anayasa değiştirmesi ile, Devletin bir dini olmasını belirten hüküm kaldırıldı. Siyasal yeminler lâikleştirildi. Ahkâm-1 Şer'iyenin tenfiz gücü kaldırıldı. Artık, Türk Devleti organları içinde, dinsel bir makam bulunmuyordu. Türk siyasal iktidar olayı, dinsel bir hükme dayanmıyordu. Fakat toplumsal yaşam, büyük ölçüde dinsellik içinde idi. Sosyal ve kültürel yaşamın hemen hemen her yönünde, beşerîlikten uzak, göksellik içindeki değerler, kurumlar, kurallar, yaşamı etkilemelerini sürdürüyorlardı. Böylece, iktidarın beşerîleştirilmesi havada kalmış oluyordu. $\mathrm{Bu}$ da demokrasileşmeyi, olumsuz yolda etkileyecek bir etmen idi. Ulusal kültür ile yaşam biçiminin, bu etmenin etkisinden kurtarılması sağlanmadıkça, temamiyle beşerî bir kurum olan demokrasinin temelleri de atılmamış olurdu.

Onun için, Türkiye; insanı bireysel yaşamının, toplumu da sosyal ilişkilerin tümü içinde çevrilip yöneten, ona egemen olan degerleri - kurumları - kuralları ortadan kaldırmak zorundan idi. Bunların yerine, beşerî değerleri -kurumları- kuralları getirmeli idi. $\mathrm{Bu}$, insanı ve toplumu değiştirme idi. $\mathrm{Bu}$ niteliği dolayısiyle de, bir devrim, bir devrimler toplamı idi. Yalnız, kendine özgü bir devrim idi : Insanı ve toplumu, «ekonomi ekseni» üzerinde; «insanı ekonomik eylemlerde bulunan bir yaratık olma, toplumu da, toplumu da ekonomik ilişkiler ortamı olma özü» içinde ele alıp değiştirmeyi öngörmekten çok, laisize ederek sosyo-kültürel yönünde değiştirmeyi öngörüyordu. İnsanın, toplumun üzerindeki dinsel kurallarının, kurumların baskısı, yasal tedbirlerle kaldırılırsa, «fitrat-ı milliye» kendi özü ile ortaya çıkardı. Bunu, Batının çağdaş düşün - değer- ve kurumları ile temas ettirirseniz; insanin bireysel yaşamı ile, toplumun sosyal oluşumlardan kurulu yaşamı, Batılı, uygarlaşmanın yolu açılmış olurdu. Bir ulusal kültürü yeniden yaratmanın olanakları doğmuş olurdu.

Bir kaşka deyimle, «iktidar» in siyasal rejim yönünden beşerîleştirilerek demokrasileştirilmesi süreci, âdeta tamamlanmıştı. (Daha sanraları, bunun tek noksanı sayılan «muhalefet-iktidar ikileşmesi» ile bu ikileşmenin işlevini görebilmesi için «özürleşme 
ortamı» nın da kurulması, siyasal rejm sorununu çözmüş gibi gelđi, herkese). Fakat, bunun toplumsal temellerinin de iyice işlenerek kurulması ve yükseltilmesi gereği, büyük bir cíddî gereksinme halinde ortada duruyordu. Yalnız, bu «toplumsal temel» kavramı, ekonomik olayı kapsayan bir yaklaşım biçimi içinde değil, ondarı soyutlaşmış bir sosyo-kültürel yaklaşım biçimi içinde anlaşılmak isteniyordu. İtidara bir önem veriliyordu. Bir ulusal refah ekonomisine yükselinmek isteniyordu. Bunun için 1931'de «iktisadí işlerde Devleti fiilen ilgilendrmek» lkesi kabul edilmişti. Bu; 1936'larda «ülkenin ekonomisini Devletin, kendi eline alması» açıklığına, Atatürk'ün kendisince kavuşturulmuştu. Fakat, hem 1931, hem 1936 açıklamaları, 1923 İzmir İktisat Kongresi'nden gelen bir temel ilke üzerinde kurulmak isteniyordu. Buna göre : yeni Devletin ulusal refah ekonomisine yükselmesi sürecinde, daima «bireylerin özel girişimlerinin ve eylemelrinin esas tutulması» temel görüşü bırakılmıyacaktı. Böylece, hem, Türklerin gözüne her zaman enternasyonal niteliği ile gözüken sosyalizmden kaçılmış olunacaktı; hem de, emperyalistleşerek Tủrkiye'yi sömürmüş olan kapitalizmin liberalizmine düşülmemiş olunacaktı.

Böylece, insana ve topluma, daha çok sosyo-kültürel yönü ile bakan bir devrimci görüş, insanı ekonomiden soyutlıyarak bu sosyo-kültürel yönü ile yakalayıp değiştirme denemesine girişti. Böylece, iktidarın beşerîleştirilerek demokrasileştirilmesinin toplumsal temelleri de atılmış olacaktı. Bu; Hilâfetsiz -ŞeyhülislâmsızŞer'iyesiz- bir Devlet yapısının da, toplum içindeki sağlam temelleri olacaktı.

Atatürk'ün, Cumhuriyeti kurarken, ondaki iktidar olayını beşerîleştirmeye çok önem verdiği, daha, T.B.M.M.'nin ilk kuruluşunda «Anayasal nitelikteki» mevzuatın hiç birine, gökselliği - dinselliği akkla getirecek bir hüküm koymamasından anlaşılır. Öyle ki, teokratik yapıdaki bir Padişahlık ile iktidar ortaklığı koymuş olan Meşrutiyet Anayasasasından sıyrıldığı ve yeni Devlete mal ettiği ilk Anayasada (28 Orak 1921) gene din ile ilgili bir hüküm koymamıştır. (Yaınız T.B.M.M.'sindeki kimi eski değerleri ve kurumları koruyucu temsilcilerin direnişini büyütmemek için, Meclisin görevleri arasına «Şeriat hükümlerinin de, uygulanması, yürütülmesi» işini de koymuştur. $\mathrm{Bu}$, bir yandan, siyasal iktidar olayı içiıde dinsel gelenekçiliğin sürdügünü gösterirse de, bir yandan, bu dinsel görevi de Meclise vererek, - Hilâftsiz-Şeyhülislâmsız bì laik Devlete doğru gidişin ilk adımmı da teşkil eder. Birinci Anayasa'dan, 20 Nisan 1924 tarihli ikinci Anayasaya kadar olan 
evrede Cumhuriyet ilàn edilmiş, Hilâfet kaldırılmıştı. Şer'iye ve Evkaf Vekâleti de kaldırılarak, eğitim birliği sağlanmıs, şeriat hükümlerinin yürütülmesi işi de, bir siyasal iktidar olayı olmaktan çıkarılmıştı.

Şimdi, toplumsal yaşamı kapsayan gökselliği de her noktasiyle arıtlamak (tasfiye etmek) gerekirdi. Buna, geniş anlamı ile lâiklik diyeceğiz. Bu laikliğin anlamını -içeriğini- boyutlamı da, pek geniş olarak, şöyle göstereceğiz. Yalnızca din ile Devletin birbirlerinden ayrılması değil; yalnızca, Devletin siyasal ve yönetimsel organları arasında dinsel kaynaktan gelen örgütlerin bulunmaması değil, yalnız, ülkenin içinde, Ahkâm-ı Şer'iyyenin, Meclis tarafından yürütülmesinin bulunmaması değil; kılık-kıyafetten tutun da kullanılan ölçülere, nikâh ve ölümüne kadar olan tüm durumlarında, insanı ve toplumu, artık beşerî kaynaktan gelen Hukuk--ahlâk kurallarının yönetmesidir lâiklik... Böylelikle, hem siyasal iktidar olayı beşerîleşmiş olacaktı; hem de bunun bir garantisi olmak üzere toplumun kendisi, toplumsal yaşamın her yönü ile beşerileşmişliğe kavuşmuş olacaktı. İktidarın beşerileştirilmesi ve demokrasileştirilmesi, bir lâik toplumsal temele dayatılmış olacaktı.

Bunun için, birey ve toplum nerelerde ve hangi noktalarda, hangi günlük eylem ve işlemlerinde, göksel (semavî) değerler kurumlar - kurallarla çevrili ise, oralara yöneltilecek ve gerekli arıtlamalar (tasfiyeler) yapılacaktı. Yapıldı da: 2 Eylül 1925'de tekkelerin, zaviyelerin, türbelerin kapatılması ve ıüm din adamları ile Devlet memurlarını kılık - kıyafetlerinin bir düzene bağlan. ması için, bir İcra Vekilleri Kararnamesi çıharıldı. 30 Kasım 1925'de de, tekkelerin - zâviyelerin - tarikatların kaldırılması, kanuna bağlandı. Bundan beş gün önce de (25 Kasım 1925'de) Şapka Kanunu çıkarıldı.

Bunları, Uluslararası Saat ve Takvim'in kabulü (Aralık 1926), Medenî Kanunun kabulü (17 Şubat 1926), Ceza Kanununun kabulü (1 Mart 1926), Borçlar Kanununun kabulü (22 Nisan 1926), Hutbelerin Türkçe okunmasının kabulü (3 Şubat 1928), Latin köklü sayıların kabulü (24 Mayıs 1928), Latin köklü Türk harflerinin kabulü (1 Kasım 1928), Liselerde Arapça ve Farsça egitiminin kaldırılması (1 Eylül 1929), ağırlık ve uzunluk ölçüsü olarak Batı ölçötlerinin kabulü (26 Mart 1931), Türkçe Kur'an okunmasının kabulü (22 Ocak 1932). Soyadının kabulü (21 Haziran 1934), lakap ve ünvanların kaldırılması (26 Kasım 1934). ruhanî giyimlerin 
görevdışı yerde ve zamanda giyilmemesinin kabulü (3 Aralık 1924) izlemiştir. Bunlara, kadınların seçme ve seçilme haklarının da geiiştirilerek kabulünü eklemek gerekir: (3 Nisan 1930'da Belıdiye Seçimlerinde, 26 Ekim 1933'de, Köy Seçimlerinde, 5 Aralık 1934'de siyasal seçimlerde).

Bütün bunlar, gene niteliyelim: Insanı ve toplumu, insanın ve toplumun ekonomik olgu içindeki yerini ele almadan, sosyo - kültürel ve politik yönlerinde yeryüzüre indirme; insanı ve toplumu göksel temalardan, etkilerden kurtarma, böylece, geleneksel - islâmcı Kamu Hukuku ilkeleri dişında çağdaş bir ulusçu, bir ulusal egemenci demokrasi kurmaya yönelmenin atılımlarıdır. Böyle bir demokrasinin zorunlu olarak lâikleşmesinin toplum içindeki temellerinin atılmasıdır. Toplum, insanın, kılığından kıyafetinden başlayıp, Tanrıya yakarışlarına, nikâhına, ticaretine, mirasına kadar tüm yeryüzü ilişkilerinde ve durumlarında ve kadın olarak siyasal olanaklarında lâikleşmez ise, siyasal iktidar da lâikleşemez ve bu nedenle de demokrasileşemez düşünü yatar bu sosyo - kültürel ve siyasal devrimlerde... Bunlar, demokrasiye kapalı bir toplumdan çıkıp, demokrasiye açık bir topluma girmek için, insanın ve toplumun sosyo - kültürel ve siyasal durumunu değiştirici eylemlerdir. İnsanın ve toplumun, lâik - çağdaş, pozitif bilime dayalı değerlere göre değişmesini öngörerek bu temelleri atan görüş, değişmenin ekonomik yönünü ve sürecini düşünmemezlik edemezdi. Düşünmüştür de.. Fakat, bu konuda kendine özgü bir «Türk örneği» bulmayı ararken Fransız devriminin değerlerinden, Batılı endüstri devrimlerinin temel verisi olan kapitalist sistemin ana çizgilerinin uzağına gidilmemiștir. Bunda, ilk Osmanlı İslâhatçıları ile başlayıp, Birinci ve İkinci Jön Türklerle süren yenileşmenin; dış egemen güçlerle, onların yerli ortaklarının «Batılı Sanayî ve Ticaret Burjuvazisi sınıfsal yararları» ekseni üzerinde gelişmesi geleneğinin etkisi vardır. Keza, Millîci Anadolu ihtilâlcilerinin, bir yandan enternasyonal kapitalizmin sömürüsünden kurtulmayı ararken, öte yandan, bir sosyalizmin enternasyonelciliğine düşmeme dikkatinin rolü vardır. Bu etki ve dikkatin rolü öyle geniş olmuştur ki, Anadolu İhtilâlinin millîcileri, halka yöneldiklerini, bir halk hükûmeti kurduklarını ileri sürdükleri halde - Atatürk'ün kendisi toprak rejimi üzerine eğildiği halde, Devleti ekonominin sahibi tanıdığı halde - ekonomideki bireysel ve kişisel girişimciliğin temelinde ve genişliğinde değer yitirmemesine dikkat etmişlerid. $\mathrm{Bu}$ nedenle, değişmenin ekonomik yönü ve süreci, orijinal gözükse de gerçekten orijinal, daha doğrusu ekonomik kalkınmavı veren 
örnek düzeyine çıkamamıştır. Beşerileşmemizin ve bu yol ile demokrasileşmemizin gelişmelerinde, bu, bir çeşit handikap olmuştur.

Fakat, demokrasileşmemizin handikap̣ı yalnızca bu değiidir. Batılı demokrasinin soyut düşünsel kurumlarinda ve anlamlarında da Batılı içeriğin nerede olduğunu, bir açık toplumun algılarının (idrâkleri) nerede olduğunu da sistemli - düzenli - bilimsel bir yol ile saptayamayışımız da bir handikaptır. Onun için, şimdi, bu saptamaya girişmek istiyoruz: 1807 Sened-i Itttifakı, göksel, Tanrısal iktidara, bir yeryüzü destek aramakla, iktidarın beşerileşerek demokrasileşme yolunu açmıştı. 1839 Tanzimat Fermanı ile 1859 Fermanı, teokratik monarşı yapısının biçimine dokunmadan özünü etkileyecek bir öğe getiriyordu: Teokratik mutlakiyet isteminin (iradesinin), Batılı İnsan Hakları Doktrininin Osmanlıya olan serpintileriyle sinırlanması.. Bu; aslında, belki, Batılı Ticaret ve Sanayi Burjuvazisinin Osmanlı ile iş yaparken doğan haklarını korumak içindi. Fakat ne de olsa, teokratik Osmanlı monarkının Tanrısal sayılan gücünün özünde bir Batılı ilke ile bir yeryüzü ilkesi ile sınirlanmasi idi de...

1876 Meşrutiyeti, daha da başka bir değişiklik-gelişme getiriyordu. Bu, Devlet yaşamında köke inen bir yenileşme olduğundan, bir devrim niteliğinde idi, Şöyleki : Orta Asya'dan beri bir Devlet geleneğimiz vardı: Tarırısal nitelikteki bir iktidarın, yeryüzünde Beğ - Hakan - Kağan - Padişah denen, halktan ayrılmış bir askersel aristokratik merkezde toplanması ve oradan, oraca, özündeki dinsel nitelik mutlakiyeti ile uygulanması... Orta Asya'dan getirdiğimiz gelenek; iktidarın, bir merkezde toplanması; bu merkezin, halktan ayrı bir askersel aristokrasinin en üst basamağ olması; halkın, ona, ancak «itaat» yolu ile, itaat ilişkisi ile bağlanması, ve hiç bir suretle, onun «karar» 1 yaratması olayına katılmaması... Devlet, böylece kurulan bir merkezsel örgüt içinde anlaşılır, kavranırdı.

İşte, 1876 Meşrutiyeti, hem teorisinde, hem yapısında bu sistemi, bir daha, biçimsel olarak geri gelemiyecek yolda değiştiriyordu.

Teorideki değişme şurada idi: Artık, iktidar, egemenlik, bir merkezde birikme tekeli içinde belirmiyecktir. Merkezsel hükümdarın yanında, egemenliğe «halk» da ortak oluyordu. Böylce, «karar» 1 yaratmada, merkezsel hükümdar tekeli kalmıyordu. Halk isteminin (iradesinin) de kararın yaratılmasina katılması olayı ortaya çıkıyordu. Ayrıca, bir ortaklık halinde varılan bu kararın da, daha 1839 'da tanınmağa başlamıs insan hakları yoluyla sınırlanması da teorideki değişmenin içinde yer alıyordu. 
Yapıdaki değişmeye gelince : İktidarnn örgütü artık bir padişahlik merkezinden halk-halka yapılan bir tek merkezli bir örgüt değildi. Uygulama da buradan çrkmıyordu. Padişahlık merkezinin yanına, bir de halk örgütü gelmiş oluyordu: Meclis-i Mebusan... Uygulama, bu ikili yapıdan geliyordu artık..

Mustafa Kemal patlaması; hem teoride, hem de yapıda, büsbütün radikal bir devrim olarak ortaya çıkmıştır: Teoride, ulusal istemi egemen kılma; ulusal kuvveti yapıcı kılma temeline iniliyordu ki, bu, iktidarı, bu kez Ulus tekeline bırakmadan başka bir şey değildir. Nitekim, iktidarın yapısı da hemen bu teoriye göre değişmiştir : Halife - Sultan, daha, hukuken ortadan kalkmamiş iken bile, onunla, ya da onun hükûmeti ile ortaklığı kabul etmeyen bir Meclis Hükûmeti sistemi kurulmuştur. Sonra, saltanat ve Halifelik, hukuken de kaldirilarak, bir Meclisli bir Cumhuriyet kurulmuştur. Bu Meclis, Ulustaki tüm egemenliğin -yargı egemenliği bölümü hariçbelirdiği bir merkez durumuna getirilmiştir. Fakat teokratik mutlakiyet teorisinin ve uygulamasının yüz yıllardan beri İslâmcı nitelikte oluşturduğu bir toplumda, Batılı bir ulusal egemenlik teorisine dayalı beşerî bir demokrasi kurulması ve hele yürütülmesi, pek kolay olmazdı. Onun için, Devlet yapısının lâikleştirilmesi yanında, bu yapıya dayanak olacakolan toplumun yapısı da lâikleştirilmiştir. Ayrıca, sosyo - kültürel değerler de değiştirilerek, ulusal secıye, ulusal fıtrat; çağdaş-laik bir siyasal iktidar batılılaşması ile, çağdaş - lâik-pozitif bilimsel verilere dayalı bir sosyal batılılaşmaya açılmıştır, açık tutulmuştur. Oluşu:nun ekonomi yönü de görülmemezlik edilmemiştir: Batı kapitalizminin liberal ilkelerinin bir sömürü düzenine vardığı görülerek, onlara itbar edlmemek istenmiştir. Devleti, ekonominin sahibi, düzenleyicisi, baş eylemcisi, girişimcisi yapan bir model aranmıștır. Yalnız bu model çinde, gene de, bireysel - kişisel girişimin, bir temel olduğu da kabul edilerek, o zamanki yüzü ile enternasyonal bir kimlikte gözüken sosyalizmden, yeni Devletin nasyonal niteliğini korutmak istenmiştir.

Bu süreç, sosyal yapıdaki geleneksel egemen kategorilerin gücit, nötralize ve demokratize edilmediği için, ilerde, onların yararlarına bir deformasyona uğramıştır. Böylece, iktidarın beşerileşmesi yoluyla demokrasileşmesi çizgisi, sapmalara ve kesintilere uğramıştır. $\mathrm{Bu}$ sapmalar içinde sosyal yapının geleneksel egemen kategorileri, bütün güçleri ile, iktidarın hem beşerîleşmesini, hem de demokrasileşmesini, gerektiği düşün özünden de uzakta tutmağa çaba göstermişlerdir. 
$\mathrm{Bu}$ nedenledir ki, bugünkü demokrasimiz, yapisal kurumlarında, baştan aşağı gelişmiş bir Batı örneği gösterdiği halde; düşün değerlerinde de, Batı sıloganları ile yuğrulu gibi gösterildiği halde; Batılı niteliğinde, oldukça noksanlarla dolu olarak kalmaktadır. Isste şimdi, bunlara eğilme zomanımız gelmiştir: Bilimsel açı, sorununun bu yönüne eğilmelidir. 